\title{
Tannmyndunargallar - klínískar áskoranir við greiningu og meðferð
}

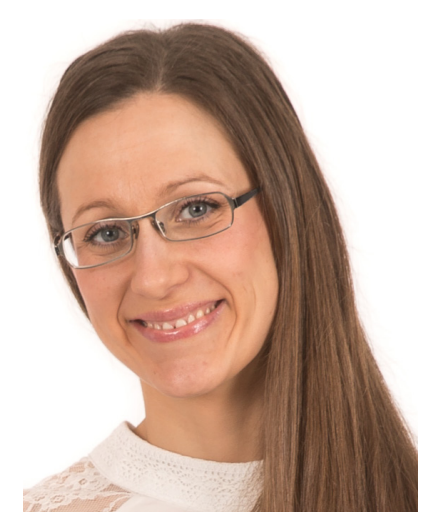

EVA GUĐRÚN SVEINSDÓTTIR, CAND.ODONT, MS, LEKTOR Í BARNATANNLAEKNINGUM, TANNLAEKNADEILD HÁSKÓLA ÍSLANDS

IVAR ESPELID, DR.ODONT, PRÓFESSOR EMERITUS Í BARNATANNLAEKNINGUM, TANNLÆKNADEILD HÁSKÓLANS Í OSLÓ

NETFANG: EGS@HI.IS TANNLAEKNABLAĐIĐ 2019; 37: 28-37

doi: 10.33112/tann.37.1.3

\section{ÁGRIP}

Myndunargallar í hörðu vefjum tanna ná yfir víðtækt svið tannlækninga og útsetja tannlækninn fyrir miklum áskorunum við greiningu og meðferðarval. pegar greina skal á milli eðlilegrar og óeðlilegrar tannmyndunar er pörf á ítarlegu mati á sjúklingi, par með talið læknisfræðilegri-, tannlæknisfræðilegri- og fjölskyldusögu, ásamt klínískri- og röntgenskoðun. Mikilvægar upplýsingar purfa að liggja fyrir og pær metnar í samhengi til að hægt sé að ákveða rétta greiningu, sem annaðhvort getur verið af erfðafræðilegum eða áunnum toga. Pegar hún liggur fyrir er meðferðarplan ákveðið á kerfisbundinn hátt par sem horft er til framtíðar. Í mörgum tilfellum eiga sjúklingar með tannmyndunargalla langa meðferð fyrir höndum. Af peim sökum er mikilvægt að tannlæknir sem meðferðinni stýrir hafi pekkingu og skilning til að veita sjúklingi bestu meðferð sem völ er á. Skoðun sjúklings er einnig mikilvæg pegar meðferðarleið er valin. Í flóknum tilfellum er oft pörf fyrir sérhæfðan tannlækni, svo sem sérfræðing í barnatannlækningum, til að samræma aðgerðir annarra sérfræðinga sem koma að meðferðinni. Í grein pessari er lögð áhersla á mikilvægustu pætti greiningar og meðferðar algengustu tannmyndunargalla.

Lykilorð: Tannmyndunargallar, glerungur, tannbein, vankölkun, vanvöxtur

\section{INNGANGUR}

Tannmyndunargallar er samheiti yfir hóp glerungs-, tannbeins-, og steinungsgalla, sem til verða af völdum truflunar í tannmyndun. Öfugt við bein pá endurnýjast tannvefur ekki á lífsleiðinni og pví eru tannmyndunargallar varanlegir. Líkja má tönnum við árhringi í trjám pannig að mögulegt er að sjá útfrá staðsetningu galla hvenær á tannmyndunartíma truflun átti sér stað.

Markmið pessarar greinar er að gefa yfirlit yfir mikilvægustu pætti greiningar og meðferðar algengustu myndunargalla tanna. 


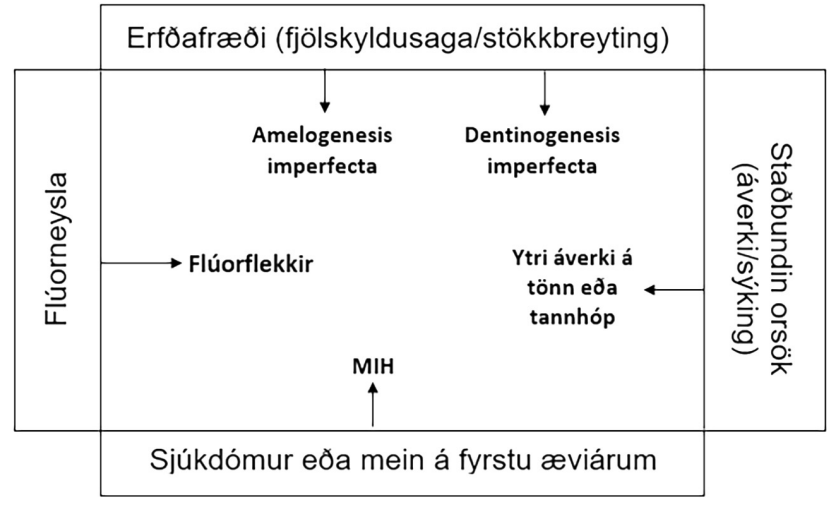

Mynd 1. Einfaldað yfirlit yfir orsök nokkurra algengustu tannmyndunargallanna.

\section{ALGENGUSTU MYNDUNARGALLAR TANNA Almennir pættir sem tengjast greiningu og meðferð}

\section{Greining}

I grundvallaratriðum eru tannmyndunargallar annaðhvort arfgengir eða orsakast af umhverfispáttum eða sjúkdómum (Mynd 1). Einnig getur arfgerð og ákveðnar erfðafræðilega stýrðar aðstæður gert einstaklinga móttækilegri fyrir peim. pegar orsök margra tannmyndunargalla er skoðuð er sú pekking sem við höfum í dag takmörkuð og engin aðgengileg erfðafræðileg próf til að staðfesta greiningu pegar genastökkbreyting er líkleg orsök gallans. Arfgengir gallar geta verið einskorðaðir við tennur, en peir geta einnig verið ein birtingarmynd almenns sjúkdóms. Gallar sem orsakast af umhverfispáttum og sjúkdómum geta takmarkast við eina tönn eða hóp nærliggjandi tanna. Peir geta einnig náð yfir fleiri tennur í kerfisbundnu mynstri og pá ákvarðast staðsetning gallans af peim tönnum og tannsvæðum sem voru í myndun pegar truflunin átti sér stað ( „,krónólógískir gallar”).

Góð heilsufarssaga er mikilvæg viðbót við nákvæma klíníska skoðun. Röntgengreining getur einnig gefið nauðsynlegar upplýsingar til að hægt sé að fá rétta greiningu. Áskorunin er að safna saman öllum mikilvægum heilsufarsupplýsingum, oft mörg ár aftur í tímann. Tannheilsusaga fjölskyldu getur einnig verið óljós, einkum ef gallinn er ekki mjög áberandi eða truflandi. Staðsetning, útlit og fjöldi gallaðra tanna eða tannsvæða er metin með hliðsjón af meðaltalsyfirlitum um tímasetningu tannmyndunar hverrar tannar. Greining byggir á heilsufarssögu og niðurstöðu klínískrar- og röntgenskoðunar. Nákvæm skráning og notkun réttra hugtaka við skráningar í sjúkraskýrslur er einnig mikilvæg og auðveldar samskipti við aðra meðferðaraðila (Box 1).
Glerungsflekkur (e. enamel opasity):

- Ófullnægjandi kölkun glerungs

- Takmarkað gegnsæi

- Litur er oft krítarhvítur, gulleitur eða brúnleitur

- Útlínur geta verið dreifðar og óljósar eða vel afmarkaðar og greinilegar

Vanvöxtur (e. hypoplasia):

- Vöntun á tannvef við uppkomu tannar

- Formfrávik í formi "pitta”, ráka eða almennt punns glerungs

Niðurbrot eftir uppkomu (e. posteruptive breakdown)

- Slit eða niðurbrot vankalkaðs glerungs eftir uppkomu tannar

- Gallarnir hafa oft skarpari kanta og útlínur en pegar um vanvöxt er að ræða

Box 1: Hugtök sem byggja á sjónrænni skoðun

Í Boxi 2 má sjá lista yfir nokkrar æskilegar greiningarspurningar til að koma í veg fyrir að mikilvægar upplýsingar verði útundan. Jákvætt svar við spurningu krefst frekari spurninga og eftirgrennslan. Pað getur sem dæmi átt við pegar grunur er um flúorósu, en pá skiptir máli að spyrja ítarlega um drykkjarvatn og flúorinnihald, hvort barnið hafi borðað eða kyngt tannkremi, hvort barnið hafi tekið flúortöflur osfrv.

Heilsufarsupplýsingar:

- Var meðganga og fæðing eðlileg?

- Hvernig var almenn heilsa barnsins fyrstu æviárin?

- Hefur barnið einhverja læknisfræðilega greiningu?

- Neytti barnið flúorbætts vatns eða flúorviðbótar í æsku?

- Hefur barnið orðið fyrir tannáverka?

- Eru aðrir í fjölskyldunni með svipaða tannmyndunargalla?

Niðurstöður klínískrar skoðunar:

- Hvaða tennur hafa gallann?

- Eru gallarnir samhverfir?

- Hafa bæði barna-og fullorðinstennur gallann?

- Eru tennurnar viðkvæmar?

- Niðurstöður röntgengreiningar?

Box 2: Hjálparspurningar við greiningu tannmyndunargalla. 


\section{Meðferð}

Meferð tannmyndunargalla er mikilvæg, bæði hvað varðar útlit og virkni tyggingarfæra. Oft eru margir meðferðarmöguleikar í boði fyrir hinar ýmsu greiningar, en mikilvægt er að hugsa málin til enda með framtíðina í huga. Alvarlegum tannmyndunargöllum fylgir gjarnan pörf fyrir yfirgripsmikla meðferð í formi tann-og munngerva, en oft er pörf fyrir tímabundnar lausnir, sem fylgja parf eftir á kerfisbundinn hátt. I flóknustu tilfellunum gæti verið pörf fyrir sérfræðitannlækni (gjarnan barnatannlækni) sem samræmir aðgerðir annarra sérfræðinga sem koma purfa að máli. Kerfisbundin nálgun, par sem meðferð er skipt í prjá fasa, er lýst í Boxi 3.

Undirbúningsfasi: Strax eftir uppkomu tanna með myndunargalla ætti nauðsynleg meðferð að hefjast. Markmið er að:

- tryggja verkjaleysi eins og hægt er

- hindra frekara niðurbrot tannvefja

- vernda viðkvæman glerung

- bæta flúornotkun til að hindra tannskemmdir og draga úr tannkuli

Eftirlitsfasi: Til 8-10 ára aldurs getur verið nauðsynlegt að halda lélegum tönnum „á floti” með minniháttar meðferð og tíðu eftirliti. Á peim tíma fæst betri mynd af hversu alvarlegur gallinn er. Fyrst pá er hægt að íhuga og skipuleggja varanlegri lausnir.

Gerð langtíma meðferðarplans: Metin skal pörf fyrir tannréttingu, úrdrátt og aðra meðferð, svo sem tann-og munngervi. Varanleg meðferð getur falið í sér:

- Míkróslípun (e. microabrasion)

- Tannhvíttun

- Viðgerðir með plastfyllingum. Plastblendi er fyrsta val ef hægt er að gera ráð fyrir eðlilegri ætingu og par með bindingu við glerung

- Gull-eða postulíns innlegg

- Heilkrónur

- Tannúrdátt og mögulega tannréttingameðferð. Úrdrátt 6 ára jaxla ætti helst að skipuleggja í samvinnu við tannréttingasérfræðing og framkvæma fyrir 10 ára aldur til að fá sem æskilegasta lokaniðurstöðu.

\section{Tannmyndunargallar sem orsakast af umhverfispáttum}

\section{Ytri skaði tanna í myndun}

Heilsufarssaga: Áverki á eina eða fleiri barnatennur á fyrstu æviárum (1-3 ára) er algeng orsök áverka á undirliggjandi tannkím fullorðinstanna. Einkum við úrslátt (e. avulsion, exarticulation) eða innslátt (e. intrusion) barnaframtanna geta tannkím fullorðinsframtanna skaddast (Mynd 2). Aðrar orsakir geta verið langvarandi umrótarsýking af völdum dreps í kviku barnajaxla. Gallaðar fullorðinstennur sjást að auki í kjölfar geislunar og háskammta lyfjameðferðar við krabbameini. Á síðustu árum, með fjölgun innflytjenda frá löndum í Austur-Afríku, hafa tannlæknar rekist á fyrirbæri sem kallast á ensku dental mutilation. Á sumum svæðum i pessum löndum er hefð fyrir pví að fjarlægja tannkím, yfirleitt barnaaugntennur, á fyrstu mánuðum eða árum ungbarna, í peirri trú að inngripið komi í veg fyrir eða lækni alvarlega sjúkdóma. Slíkt inngrip getur valdið skaða sem getur birst sem vöntun á fullorðinsaugntönnum, vanvöxtur, óeðlilegur tannproski, tannlíkar fyrirferðir (e. odontome) og uppkomuvandi aðlægra nágrannatanna (1).
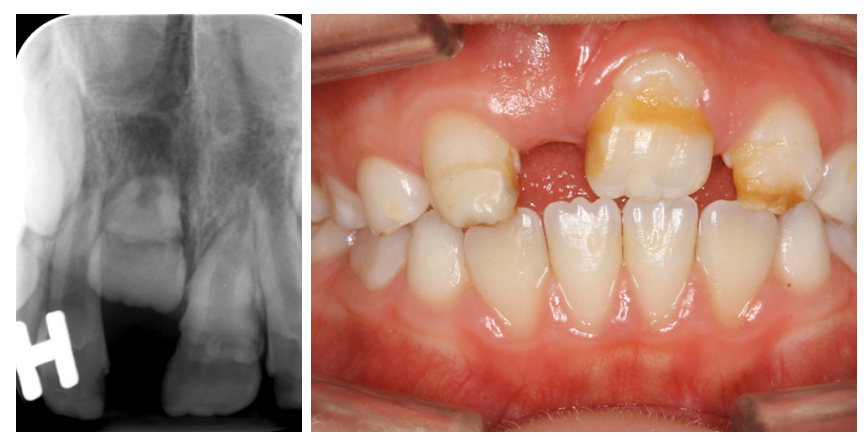

Mynd 2. 9 ára stúlka eftir tannáverka, innslátt (e. intrusion) á \#51 og \#61, við 1,5 árs aldur. Allar framtennur með afmyndaðar krónur og vanvöxt glerungs (A). Tönn \#11 var fjarlægð sökum verulegs myndunargalla og stöðvunar rótarproska (B).

Klínisk einkenni: Gallarnir geta verið mjög ólíkir eftir pví hvenær á tannmyndunarskeiði truflun verður, hversu öflug truflun er og hversu lengi hún varir. Klínískt geta peir verið allt frá vægum glerungsflekkjum til mikils vanvaxtar glerungs, afmyndunar krónu og rótar (Mynd 2), stöðvunar rótarproska og tannvöntunar tannar eða tanna sem fyrir truflun verða (2). 


\section{Flúorósa (e. dental fluorose)}

Heilsufarssaga: Flúorósa er afleiðing of mikillar inntöku flúors yfir allt eða hluta tannmyndunartímabils. Ofskömmtun flúortannkrems eða flúortaflna getur orðið og er algeng orsök vægra flúorflekkja (3). Í sumum hópum innflytjenda má greina alvarlega flúorósu, sem er afleiðing hás flúorinnihalds í drykkjarvatni pess lands sem peir koma frá (Mynd 3).

Klínísk einkenni: Flúorósa getur haft mjög mismunandi birtingarmynd par sem alvarleikinn fer eftir umfangi flúorinntöku, aldri barns pegar inntaka á sér stað og hversu lengi inntakan er of mikil. Bæði barna- og fullorðinstennur geta orðið fyrir áhrifum, barnatennur pó síður par sem pær kalka að mestu fyrir fæðingu. Brjóstamjólk inniheldur tiltölulega lítið af flúor, jafnvel pótt drykkjarvatn móður sé flúorríkt. Árið 1978 lögðu Thylstrup og Fejerskov til greiningarskala fyrir umfang og alvarleika glerungsgalla af völdum flúorósu (4). TF-skalinn er auðveldur í notkun og hentar vel við vefjafræðileg frávik sem fyrir koma í flúorósu (Box 4, Mynd 3).

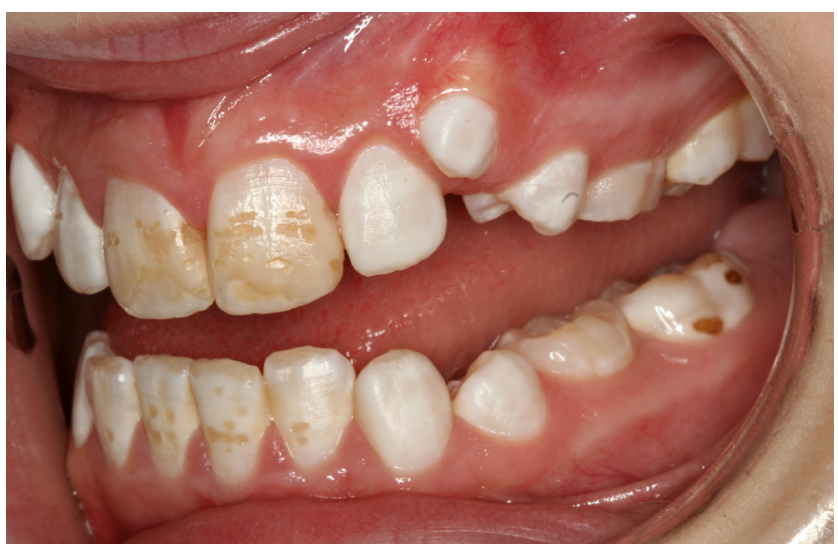

Mynd 3. 12 ára stúlka með flúorósu. TF-gildi 4-6. Glerungsgallar eru samhverfir, glerungur hefur flagnað af og mislitun áberandi á miðframtönnum, hliðarframtönnum í neðri gómi og á \#36 (TF-gildi 5-6). Aðrar tennur er kritarhvítar og án glerungstaps (TF-gildi 4).

\section{Tf-gildi Klínisk einkenni}

$0 \quad$ Eðlilegt gegnumskin glerungs breytist ekki með loftpurrkun yfirborðs.

1 Punnar, hvítar línur á yfirborði, sem svara til perikymata.

2 Sléttfletir: Greinilegri hvítar línur sem geta myndað lítil ský yfir allt yfirborðið.

Okklúsalfletir: Dreifð, ógegnsæ (e. opaque) svæði, minni en 2 mm í pvermál, ásamt greinilegum flekkjum á kúspum.

3 Sléttfletir: Dreifð, ógegnsæ svæði með sýnilegum perikymata línum.

Okklúsalfletir: Greinileg ógegnsæ svæði, sem gjarnan skarast yfir í hvert annað. Slitin svæði nánast eðlileg ásýndar, p.e. gallalaus, en hafa yfirleitt umlykjandi band með ógegnsæum glerungi.

Sléttfletir: Allt yfirborðið mjög ógegnsætt eða krítarhvítt. Slitnir hlutar yfirborðs, geta virst minna gallaðir.

Okklúsalfletir: Allt yfirborðið mjög ógegnsætt. Slit oft mikið og greinilegt fljótlega eftir uppkomu tanna.

$4 \quad$ Slétt-og okklúsalfletir: Allt yfirborðið mjög ógegnsætt og sýnilegir pittir (glerungstap), minni en 2 mm í pvermál.

5 Sléttfletir: Pittir mynda regluleg lárétt bönd, pynnri en 2 mm í lóðréttu pvermáli.

Okklúsalfletir: Samfljótandi svæði með glerungstapi (minna en 3 mm í pvermáli).

6 Sléttfletir: Glerungstap á minna en helmingi yfirborðs.

Okklúsalfletir: Formfræðilegt frávik af völdum samruna pitta og yfirgripsmikils slits.

7 Slétt-og okklúsalfletir: Glerungstap á meira en helmingi yfirborðs.

8 Slétt- og okklúsalfletir: Tap á meirihluta glerungs með formfræðilegum frávikum á formi tannar. Tannhálsasvæði oft heilbrigð og án galla.

Box 4

Meðferð: Í vægum tilfellum er aðalvandamálið útlitslegs eðlis vegna mislitra hvítra og brúnna svæða á glerungi. pá liggja hinir vankölkuðu flekkir yfirleitt yst í glerungi og má oft fjarlægja pá með microabration-tækni og mögulega tannlýsingu í kjölfarið (Mynd 4) (5). Í alvarlegri tilfellum getur verið pörf fyrir viðgerðir til að hylja gallana, annaðhvort með plastblendi-eða glerjónómerfyllingu eða jafnvel postulínsskel (fasettu). Í alvarlegustu tilfellum er pörf fyrir enn umfangsmeiri meðferð sambærilegri alvarlegum tilfellum af Amelogenesis imperfecta (umfjöllun síđar) (2). 

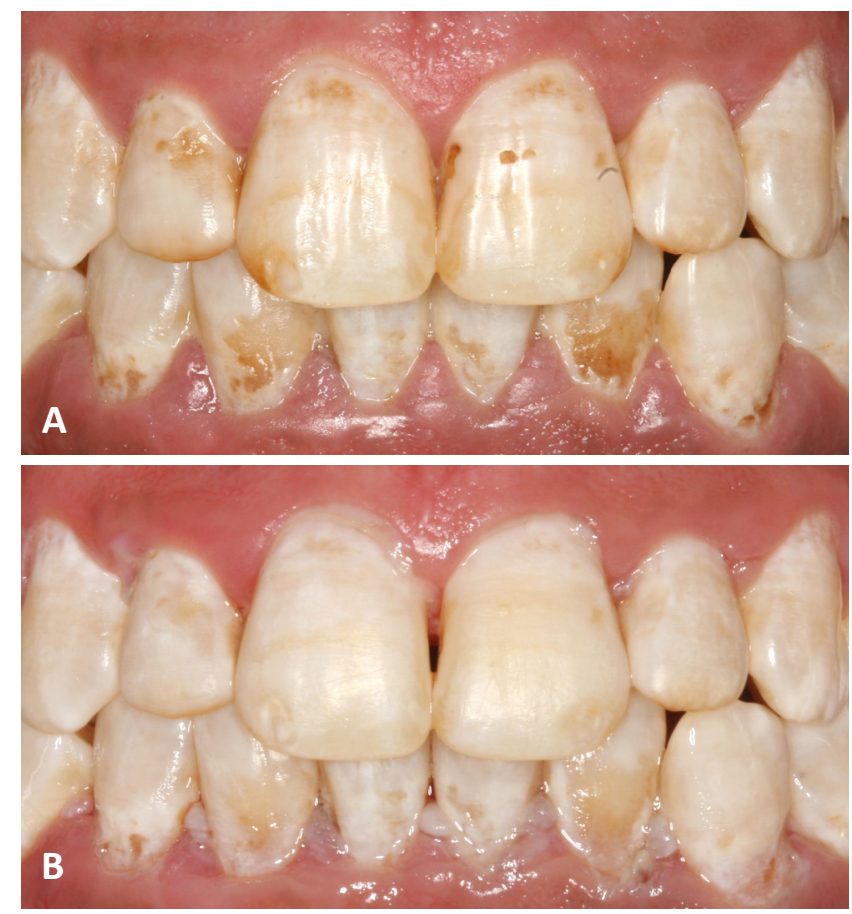

Mynd 4. 18 ára stúlka sem ólst upp í Afríku par sem hún neytti drykkjarvatns með miklu flúorinnihaldi. Hún er með TF-gildi 5-7 af flúorósu (A). Framtennur í efri og neðri gómi voru meðhöndlaðar með microabration (B) og siðar með tannhvittun.
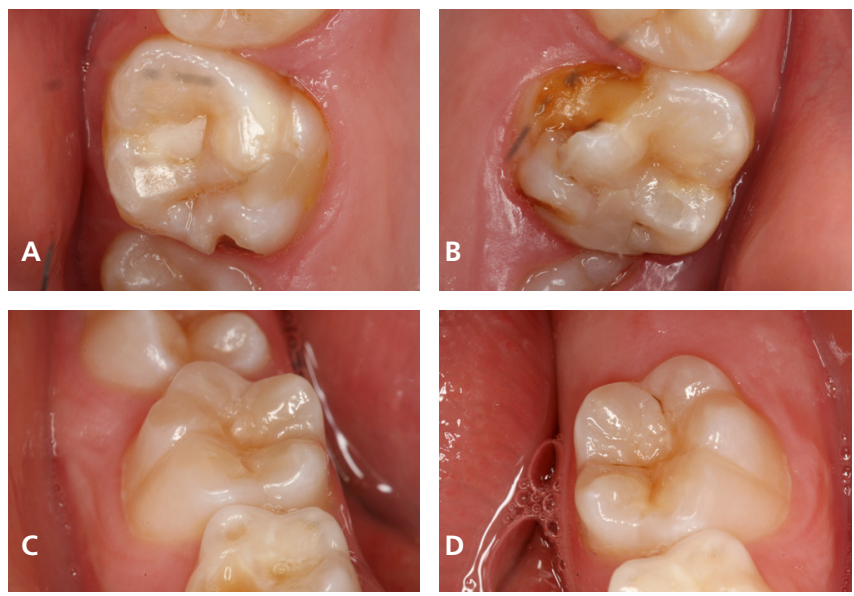

Mynd 5. 13 ára stúlka með miðlungs alvarlegan MIH, sem hefur versnað vegna endurtekins niðurbrots glerungs eftir uppkomu tanna. Greinilegur munur er á umfangi galla i 6 ára jöxlunum fjórum. Tönn \#16 hefur orðið fyrir niðurbroti eftir uppkomu (e. posteruptive breakdown) distalt, \#26 hefur enn umfangsmeiri galla með stórum niðubrotnum svæðum, ásamt áður gerðum plastblendisfyllingum. \#36 hefur aðeins lítinn vankalkaðan flekk okklúsalt en \#46 er alveg heilbrigður. Slik ósamhverf dreifing er dæmigerð fyrir MIH.

\section{MIH (Molar-Incisor hypomineralization)}

Molar Incisor hypomineralization (MIH) er eitt form glerungsgalla, sem er skilgreint sem vankölkun af kerfisbundnum uppruna á einum til fjórum 6 ára jöxlum og mögulega einnig framtönnum (6). Ólíkar nafngiftir hafa verið notaðar um meinið, en árið 2001 var hugtakið MIH lagt til af Weerheijm, Jälevik og Alaluusua (6) og pað nafn er nú orðið alpjóðlega nafn pess. MIH er einn af algengustu tannmyndunargöllum sem pekkjast, með tíðnina 14\% í Noregi (7), 18\% í Svípjóð og 17\% í Finnlandi (8).

Heilsufarssaga: Orsakafræði MIH er mikið til ópekkt, en ýmsar mögulegar orsakir verið ræddar (Box 5) (9). Ekki er ólíklegt að um fjölpátta orsök sé að ræða, par sem samlegðaráhrif eru á milli líffræðilegra og ytri pátta.

- Læknisfræðilegt ástand fyrir fæðingu

- Fyrirburar

- Léttburar

- Súrefnisskortur við fæðingu

- Barnasjúkdómar sem valda háum líkamshita

- Sjúkdómar í loftvegum

- Sýklalyf (amoxicillin)

- Bólusetningar

- Truflun í kalsíum,eða fosfat efnaskiptum

- Langvarandi brjóstagjöf

- Sein innkoma grauta eđa mjólkurábótar í fæði ungabarna

- Umhverfiseitrun, s.s. PCB og díoxín

Box 5: Mögulegir orsakapættir MIH.

Klínísk einkenni: Til að uppfylla greiningarkröfur MIH parf að minnsta kosti einn 6 ára jaxl að hafa gallann. Auk galla í framtönnum geta aftari barnajaxlar og kúspatoppar fullorðinsaugntanna orðið fyrir barðinu. Alvarleiki er á breiðu bili, en pað sem greinir MIH frá mörgum öðrum myndunarfrávikum er að gallarnir ná aðeins til peirra tanna sem voru í myndun í kringum fyrsta æviár. Gallarnir hafa oft ósamhverfa dreifingu i tannsettinu (Box 6, Mynd 5). 
- 6 ára jaxlar, framtennur, aftari barnajaxlar og fullorðinsaugntennur.

- Fjöldi gallaðra tanna mismunandi.

- Ósamhverf dreifing í tannsettinu.

- Vægari form: hvítir afmarkaðir flekkir með hörðu og vel kölkuðu yfirborði.

- Alvarlegri form: gulbrúnn og gegndræpur glerungur með niðurbroti eftir uppkomu.

- Gallaður glerungur greinist yfirleitt auðveldlega frá heilbrigðum glerungi.

- pví mislitaðri flekkir eða gölluð svæði pví gegndræpari.

- Cervical, priðjungur glerungs á gölluðum tönnum er yfirleitt heilbrigður.

- Tennur mjög viðkvæmur.

- Hröð próun tannátu.

Boks 6: Klínísk einkenni MIH.

Klínísk vandkvæði sem tengjast $\mathrm{MIH}$, ofurviðkvæmar tennur, erfiðleikar með að ná góðri staðdeyfingu, hröð og ágeng tannáta og tannlæknakvíði, eru vel pekkt $(10,11)$. Ofurviðkvæmni tanna er sá páttur sem einna mikilvægast er að taka tillit til, bæði almennt og við tannlæknameðferð, pví slík viðkvæmni getur verið mjög truflandi fyrir sjúklinga. Rannsóknir hafa sýnt að MIH-jaxlar geta haft aukinn fjölda sársaukanema, mögulega af völdum krónískrar bólgu í kviku tanna (12). Kvikan getur orðið fyrir ertingu af völdum baktería sem ferðast í gegnum hinn vankalkaða glerung, jafnvel pótt gallarnir séu lítið sýnilegir (13). Af peim sökum getur áreiti eins og loftpurrkun, sondupreifing og tannburstun valdið miklum verkjum hjá MIH-sjúklingum sem getur valdið pví að tannhirðu sé ábótavant. Að auki hafa MIH-sjúklingar aukna áhættu á tannátu (14) sem geta valdið enn frekari verkjum. Umönnun MIH-tanna er pví sérstaklega mikilvæg, bæði til að forðast vandkvæði tengd tannkviku og próun verkja.

Meðferð: Vegna aukinnar áhættu á tannlæknakvíða og oft yfirgripsmikillar meðferðar er mikilvægt að tannlæknar og aðstoðarfólk geri allt sem pað getur til að koma i veg fyrir próun á fyrrnefndum kvíða. Góð staðdeyfing er forsenda pess að pað takist og pví skal ávallt taka frá nægilegan tíma í verkið, notast við góða deyfingatækni og ekki síst að trúa verkjaupplifun sjúklings. Rafstýrðar deyfingavélar, t.d. The Wand (Wand*Dental, Inc., Livingston, New Jersey, USA), slæving í formi glaðlofts og verkjalyf fyrir meðferð geta reynst vel.
Regluleg flúorlökkun hefur tannátuhemjandi áhrif og getur dregið úr ofurviðkvæmni tanna. Við umfangsmikla galla er pörf á viðgerðum. Slíkar meðferðir geta verið krefjandi pví binding fyllinga við hinn vankalkaða glerung er veik, sem eykur líkurnar á að fyllingar mistakist. Að auki veldur endurtekið niðurbrot galla eftir uppkomu vandkvæðum. Léleg binding fyllinga er afleiðing lélegrar ætingar (15). pví er aðeins mælt með plastblendisfyllingum ef mögulegt er að fjarlægja allan gallaðan glerung og ná pannig bindingu við heilbrigðan glerung. Við enn umfangsmeiri galla er mælt með hefðbundnum glerjónómer sem langvarandi bráđabirgðalausn. Enn endingarbetri lausn eru stálkrónur, steypt innlegg eđa heilkrónur. Stálkrónur gefa góða vörn fyrir gallaða barna-og fullorðinsjaxla og endast vel. Í alvarlegum tilfellum er úrdráttur gallaðra jaxla hinsvegar góð meðferð, einkum pegar tennur eru fjarlægðar vel fyrir uppkomu 12 ára jaxla. Pá má búast við mesialfærslu 12 ára jaxla í stæði 6 ára jaxla, sem tryggir sjálfkrafa lokun bils sem úrdráttur 6 ára jaxla skilur eftir (Box 3) (16).

\section{Tannmyndunargallar af völdum genagalla}

\section{Amelogenesis imperfecta}

Amelogenesis imperfecta (Al) nær yfir hóp arfgengra sjúkdóma, sem eru klínískt og erfðafræðilega ólíkir en einkennast allir af galla í glerungi tanna. Meinið var fyrst skilgreint sem glerungsgalli árið 1945 af Weinmann et al, en var endurskilgreint árið 2007 af Crawford et al:

„Al nær yfir hóp tannsjúkdóma af erfðafræðilegum uppruna sem hafa áhrif á uppbyggingu og klínískt útlit glerungs á öllum eða næstum öllum tönnum, á meira eđa minna sama máta og getur tengst formfræðilegum eða lífefnafræðilegum breytingum á öðrum stöðum líkamans. Al er myndunargalli í tannglerungi (einkennist af vanvexti (hypoplasia) og/eða vankölkun (hypomineralization)) sem sýnir autosomal ríkjandi-, autosomal víkjandi-, kynbundið- og óreglubundið erfðamynstur, ásamt óreglubundnum tilfellum" (17).

Tíðni Al virðist vera ólík milli heimssvæða, allt frá 1:14.000 í USA, til 1:700 í Svípjóð $(18,19)$.

Heilsufarssaga: Al orsakast af stökkbreytingum í genum sem ábyrg eru fyrir glerungsmyndun. Meinið getur erfst eftir öllum pekktum erfðaleiðum, en oft verða nýjar stökkbreytingar og í slíkum tilfellum er meinið ekki 
pekkt í fjölskyldunni. Al-stökkbreytingar hafa fundist í mörgum ólíkum genum, sem öll hafa hlutverki að gegna við glerungsmyndun.

Mikill erfðafræðilegur breytileiki og fjölbreytni i svipgerðum meinsins gerir nákvæma undirgreiningu flókna. Viss form Al geta t.d. svipað til flúorósu og pví er heilsufarssaga mikilvæg til að útiloka ytri áhrifapætti pegar greining er gerð.

Klínísk einkenni: Al nær til allra tanna í báðum tannsettum, en getur verið alvarlegri í fullorðinstannsetti í nokkrum tilbrigðum (2). Alvarleikinn getur verið allt frá mildum göllum, par sem glerungur er mislitur og án taps á tannvef, til alvarlegri galla, par sem glerungur er mjúkur og flagnar auðveldlega af eða vantar frá upphafi. Sjúklingar geta pjáđst af tannkuli, sem getur valdið erfiðleikum við að borða, viðhalda góðri tannhirðu og að gangast undir tannmeðferðir. prjár aðaltýpur af Al (sjá Box 7-9) eru pekktar, en samsetningar pekkjast einnig.

- Megindlegur (e. quantitative) galli, par sem glerungur er óeðlilega punnur staðbundið eða almennt.

- Glerungur er grófur, sléttur eða með dældum (pittum) eða rákum.

- Snertipunkta vantar oft við almenna hýpóplastíska týpu.

- Tuflun á tannuppkomu.

- Skeletalt opið bit á framtannasvæði mögulegt.

- Á röntgenmynd er eðlilegur röntgenpéttnimunur milli glerungs og tannbeins.

Box 7: „Hypoplastic” týpa Al (vanvöxtur).

- Eigindlegur (e. qualitative) galli, par sem glerungur er vankalkaður, staðbundið eða almennt.

- Glerungur hefur eðlilega pykkt, en getur verið stökkur og viðkvæmari fyrir sliti.

- Glerungur flagnar oft eða brotnar eftir tannuppkomu.

- Ógegnsæ hvít eða gulbrún mislitun glerungs.

- Ofurviðkvæmni.

- Minni röntgenpéttni milli glerungs og tannbeins.
- Eigindlegur (e. qualitative) galli, par sem glerungur er mjög illa kalkaður og að hluta til verulega mýkri.

- Gul eða gulbrún mislitun glerungs.

- Glerungur slitnar fljótt.

- Tannuppkomu getur seinkað.

- Skeletalt anteriort opið bit mögulegt.

- Oft umfangsmikill supragingival tannsteinn.

- Ofurviðkvæmni.

- Lítill munur á röntgenpéttni milli glerungs og tannbeins.

Box 9: „Hypocalcification" týpa af Al (vankölkun).
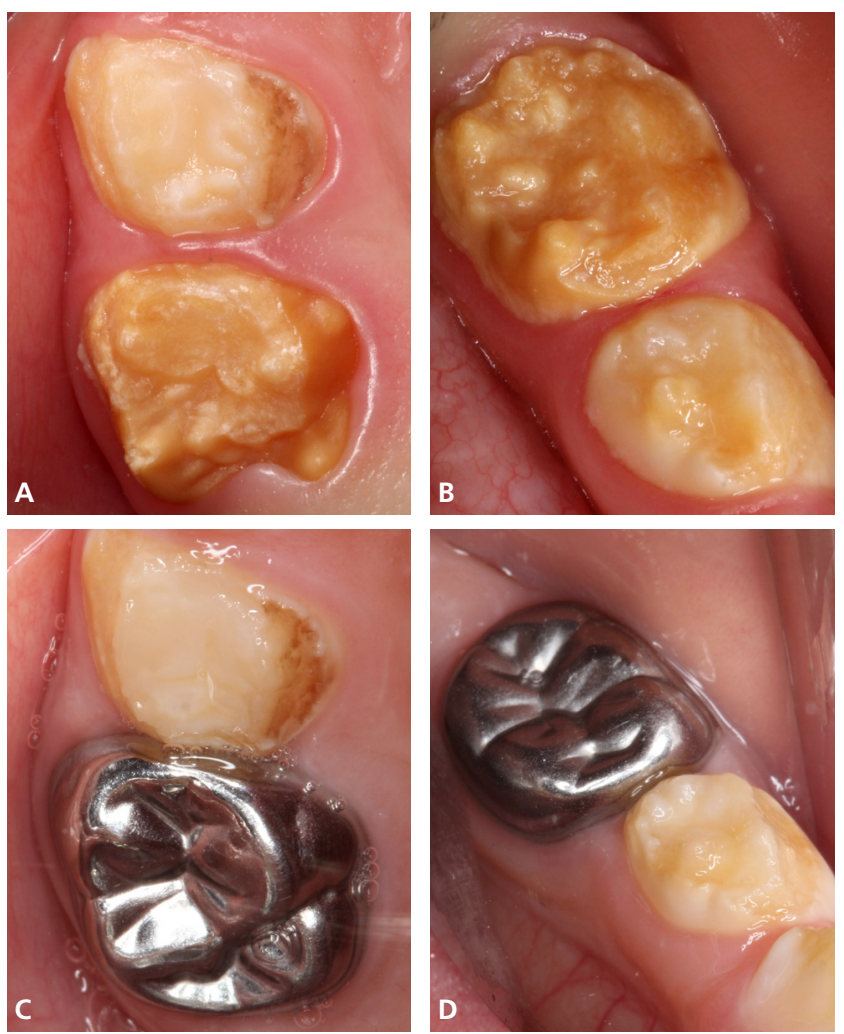

Mynd 6. 3 ára gamall drengur með Amelogenesis imperfecta, hypomaturation týpu, i samblandi við hypoplastic týpu. A-B sýnir tennur \#55 og \#75 fyrir meðferð með stálkrónum. pá pjáðist hann af miklu kuli pegar hann borðaði og burstaði tennur. C-D sýnir sömu tennur eftir meðferð með stálkrónum og var drengurinn orðinn einkennalaus.

Box 8: „Hypomaturation” týpa Al (vankölkun) 
Meðferð: Aðalvandkvæði Al eru slakt útlit, viðkvæmni tanna og erfiðleikar tengdir tyggingu. Annað stórt vandamál getur verið tap á tannvef vegna niðurbrots eftir uppkomu og tannslit, en slíkt getur aftur leitt til lækkunar á bithæð. Viðunandi meðferð er pví mjög mikilvæg fyrir pessa sjúklinga, en einnig parf að huga að andlegri heilsu (20). Í vægum tilfellum getur tíðara eftirlit og flúorlökkun tanna verið nægilegt inngrip. Í alvarlegri tilfellum getur verið pörf fyrir frekari meðferð, bæði í barna-og fullorðinstannsetti. prátt fyrir að barnatennur hafi yfirleitt mildari galla en fullorðinstennur, getur aukin viðkvæmni og yfirgripsmikið slit orðið vandamál. Í peim tilfellum er ráðlegast og endingarbest að vernda barnajaxla með stálkrónum (Mynd 6) (2). Stálkrónur koma einnig til greina á alvarlega gallaða fullorðinsjaxla, en aðrir möguleikar eins og plastblendis-eða postulínsonlay og gullkrónur gætu einnig hentað (2). I alvarlegum Al-tilfellum er slík meðferð mikilvæg til að varðveita bithæð og heilbrigði tannsettsins. Binding við Al-glerung er möguleg í flestum tilfellum og pví er ekkert sem mælir á móti notkun plastblendis.

pegar barnið vex úr grasi og útlitið skiptir meira máli, geta postulínsskeljar eða krónur átt vel við. Frekari uppkoma tanna og mislitun viðgerðarbrúna með tímanum kallar á reglubundið eftirlit. Pví fyrr sem tann-og munngervi (prótetískar lausnir) eru notuð, pví fyrr verður pörf fyrir endurgerð peirra fyrstu árin.

\section{Dentinogenesis imperfekta}

Dentinogenesis imperfecta (DI) er algengasti tannmyndunargalli sem herjar á tannbein, með tíðnina 1:82.000 samkvæmt sænskri rannsókn (21) og pví mun sjaldgæfari en Al.

Heislufarssaga: DI orsakast af stökkbreytingu í DSPPgeni, sem spilar stórt hlutverk í myndun tannbeins (22). Par sem meinið stafar af ríkjandi genagalla á A-litningi (e. autosomal dominant) með næstum fullri sýnd (penetration), háu tjáningarstigi (e. high expressitivity) og fáum nýjum stökkbreytingum, pekkist pað oft í fjölskyldu og auðvelt er að kortleggja hver hefur eða hefur haft DI.

Klinísk einkenni: Á sama hátt og Al pá nær DI til allra tanna, en ólíkt Al pá verða barnatennur yfirleitt verr úti en fullorðinstennur (Box 10).
- Allar barna,og fullorðinstennur hafa gallann, en á ólíkan hátt. Barnatennur verða oftast fyrir alvarlegri galla.

- Mismunandi gráblá til brúnleit mislitun, ásamt gegnumskini sem gefur útlit glergljáa (e. opalescent).

- Glerungur hefur oft smásprungur og er útsettur fyrir niðurbroti eftir uppkomu.

- Umfangsmikið tannslit.

- Tannholsvandamál möguleg.

- Röntgeneinkenni: perulaga krónur, stuttar og mjóar rætur og pröngt tannhol (e. obliterated).

Box 10: Klínisk einkenni DI
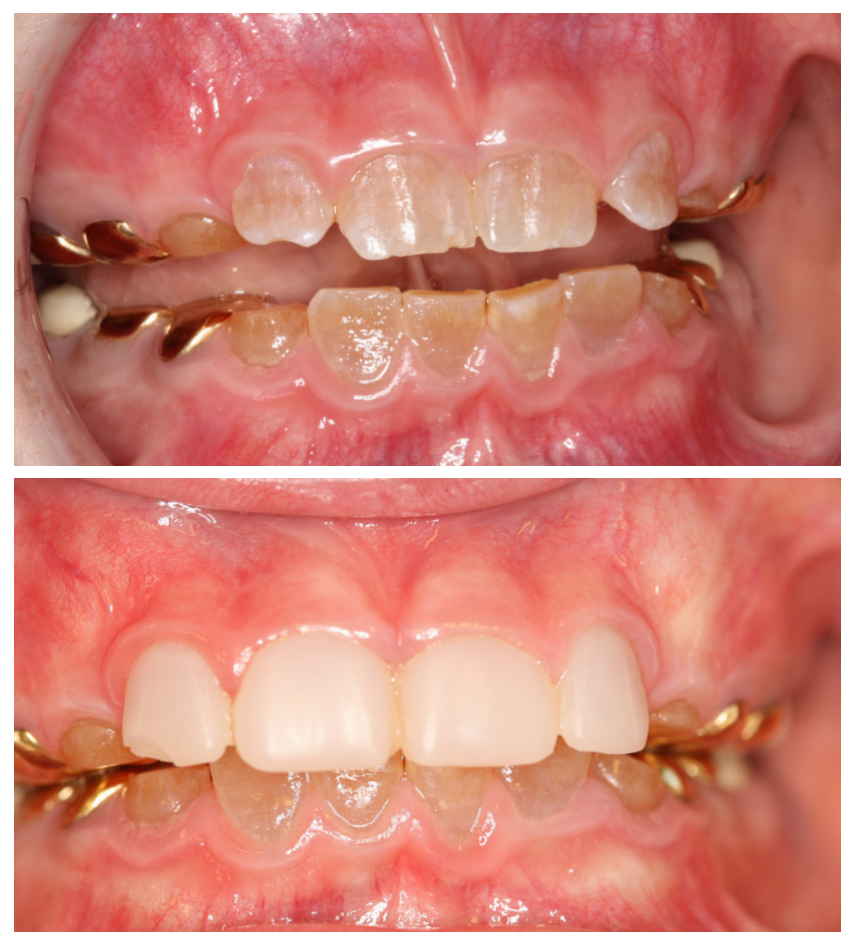

Mynd 7: 9 ára stúlka með alvarlegt form af dentinogenesis imperfecta. Við 3ja ára aldur voru settar gullhettur á alla barnajaxla og við 8 ára aldur, heilkrónur á 6 ára jaxla (A). Við 9 ára aldur voru forgerðar plastblendisskeljar límdar á fullorðinsframtennur efri góms, en insisal kantur \#12 (B) hafði brotnað við næsta eftirlit. Petta sýnir hversu yfirgripsmikil meðferð við alvarlegum myndunargalla getur verið. Mynd: Ingvild J. Brusevold. 
Meðferð: Slakt útlit og slit tanna eru aðalvandkvæði DI. Mikið slit getur leitt til tannkvikuvandamála. Líkt og við Al er stálkrónumeðferð rétt nálgun við meðferð barnajaxla og mælt er með að sú meðferð hefjist um leið og slit eða niðurbrot greinist. Koma má í veg fyrir glerungssprungur og slit á fullorðinsjöxlum með bitskinnu að nóttu til. Verði slíkur skaði má gera við hann með stálkrónum, heilkrónum úr postulíni eða gulli, glerjónómer eða plastblendi (Mynd 7). Pegar barnið verður eldra má skipta peim út fyrir postulínsheilkrónur, plastblendisfyllingar eða postulínsskeljar á framtannasvæði.

\section{Samantekt}

Pegar tannmyndunargalli hefur verið greindur skal meðferðarplan gert á kerfisbundinn hátt par sem horft er til framtíðar, bæði með tannheilsu og almenna vellíðan sjúklings í huga. Hann og forráđamenn eiga að taka pátt í gerð meðferðarplansins, en pað krefst ítarlegrar fræðslu um meinið, meðferðarmöguleika og horfur. Sjúklingar eiga í mörgum tilfellum langa meðferð fyrir höndum og vandamál sem upp koma leysast betur og auðveldar í samvinnu og gagnvæmu trausti milli sjúklings, forráðamanna og meðferðaraðila. Gæði góðrar tannlæknapjónustu ákvarðast best af pví pjónustustigi sem hinum mest purfandi býðst. pegar um tannmyndunargalla er að ræða er mikilvægt að meðferðaraðilar hafi sérpekkingu á slíkum göllum og meðferð peirra. Barnatannlæknar hafa slíka pekkingu og geta komið til hjálpar pegar purfa pykir.

\section{Fyrri saga greinar}

Grein pessi er unnin úr norskri grein sem birtist í Aktuel Nordisk Odontologi 2016, Dentale utviklingsforstyrrelser kliniske utfordringer i diagnostikk og behandling (Aktuel Nordisk Odontologi. 2016;8:126-145). Slóð: https://www. idunn.nolaktuel_nordisk_odontologi/2016/01/dentale_ utviklingsforstyrrelser_-_kliniske_utfordringer_i_d

Greinin er birt hér í minningu góðs vinar míns og leiðbeinanda, Ivars Espelid, sem lést eftir stutt veikindi pann 19. desember 2017. Ivar lagði tannlæknavísindum mikið til og var pekktur frumkvöðull innan barnatannlæknisfræði, m.a. á sviði tannsjúkdómafræða, röntgenfræða og tannmyndunargalla. Ég á honum ótalmargt að pakka og mun ávallt minnast Ivars sem pess mikla fagmanns, kollega og ekki síst pess trausta vinar sem hann var.

\section{Heimildir}

1. Espelid I, Agnalt R. Fjerning av tannanlegg i afrikansk folkemedisin. Nor Tannlegeforen Tid 2009;119(5):294-297.

2. Espelid I, Haubek D, Jalevik B. Developmental defects of the dental hard tissues and their treatment. I: Koch G, Poulsen S, editors. Peadiatric Dentistry, a clinical approach. West Sussex: Wiley Blackwell, 2009:233-263.

3. Wang NJ, Gropen AM, Ogaard B. Risk factors associated with fluorosis in anonfluoridated population in Norway. Community Dent Oral Epidemiol 1997;25(6): 396-401.

4. Thylstrup A, Fejerskov O. Clinical appearance of dental fluorosis in permanent teeth in relation to histologic changes. Community Dent Oral Epidemiol 1978;6(6):315-328.

5. Altenau AC, Tveit AB. Skjemmende flekker i emaljen behandlet med mikroabrasjon og bleking - et pasienttilfelle. Nor Tannlegeforen Tid 2002;112(8):422-426.

6. Weerheijm KL, Jalevik B, Alaluusua S. Molar-incisor hypomineralization. Caries Res 2001 Sep-Oct;35(5):390-391.

7. Schmalfuss A, Tveit AB, Espelid I, Crossner CG, Stenhagen KR. The prevalence of molar incisor hypomineralization in 16-year old adolescents in Northern Norway. Caries Res 2013 Sep;47(5):433-531

8. Wuollet E, Laisi S, Salmela E, Ess A, Alaluusua S. Background factors of molar-incisor hypomineralization in a group of Finnish children. Acta Odontol Scand 2014 Nov;72(8):963-969.

9. Alaluusua S. Aetilogy of molar-incisor hypomineralization: a systematic review. Eur Arch Paediatr Dent 2010 Apr;11(2):53-58.

10. Mast P, Rodriqueztapia MT, Daeniker L, Krejci I. Understanding MIH: definition, epidemiology, differential diagnosis and new treatment guidelines. Eur J Paediatr Dent 2013 Sep;14(3):204-208.

11. Jalevik B, Klingberg GA. Dental treatment, dental fear and behaviour management problems in children with severe enamel hypomineralization of their permanent first molars. Int J Paediatr Dent 2002 Jan; 12(1): 24-32.

12. Rodd HD, Boissonade FM, Day PF. Pulpal status of hypomineralized permanent molars. Pediatr Dent 2007 Nov-Dec;29(6):514-520.

13. Fagrell TG, Lingström $P$, Olsson $S$, Steiniger $F$, Norén JG. Bacterial invasion of dentinal tubules beneath apparently intact but hypomineralized enamel in molar teeth with molar incisor hypomineralization. Int J Paediatr Dent 2008 Sep;18(5):333-340.

14. Jalevik B, Klingberg G. Treatment outcomes and dental anxiety in 18year-olds with $\mathrm{MIH}$, comparison with healthy controls - a longitudinal study. Int J Paediatr Dent 2012 Mar;22(2):85-91.

15. Jalevik B, Dietz W, Norén JG. Scanning electron micrograph analysis of hypomineralized enamel in permanent first molars. Int J Paediatr Dent 2005 Jul;15(4):233-240.

16. Jalevik B, Moller M. Evaluation of spontaneous space closure and development of permanent dentition after extraction of hypomineralized permanent first molars. Int J Paediatr Dent 2007 Sep;17(5):328- 335.

17. Crawford PJ, Aldred M, Bloch-Zupan A. Amelogenesis imperfecta. Orhpanet J Rare Dis 2007 Apr 4;2:17.

18. Witkop CJ. Hereditary defects in enamel and dentin. Acta Genet Stat Med 1957;7(1):236-239.

19. Backman B, Holm AK. Amelogenesis imperfecta: prevalence and incidence in a northern Swedish county. Community Dent Oral Epidemiol 1986 Feb;14(1):43-47.

20. Coffield KD. The psychosocial impact of developmental dental defects in people with hereditary amelogenesis imperfecta. J Am Dent Assoc 2005 May;136(5):620-630.

21. Malmgren B. Clinical, histopathologic and genetic diagnosis in osteogenesis inperfecta and dentinogenesis imperfecta. Stockholm: Karolinska Institutet; 2004.

22. Maciejewska I, Chomik E. Hereditary dentine diseases resulting from mutations in DSPP gene. J Dent 2012 Jul;40(7):542-548. 


\title{
Dental developmental disturbances - clinical challenges in diagnostics and treatment
}

\author{
EVA GUĐRÚN SVEINSDÓTTIR, DDS, MS, LECTOR AND HEAD OF PEDIATRIC DENTISTRY, FACULTY OF ODONTOLOGY, \\ UNIVERSITY OF ICELAND \\ IVAR ESPELID, DR.ODONT, PROFESSOR EMERITUS AND HEAD OF PEDIATRIC DENTISTRY, FACULTY OF \\ ODONTOLOGY, UNIVERSITY OF OSLO
}

E-MAIL: EGS@HI.IS, ICELANDIC DENT J 2019; 37: 28-37

doi: 10.33112/tann.37.1.3

Developmental defects of dental hard tissues comprise a comprehensive field within dentistry that exposes the dentists to great challenges in terms of diagnostics and treatment decisions. Distinguishing between normal and pathological dental development requires careful evaluation of the patient, including medical, dental, and family history, and clinical and radiographic examination. All important information needs to be gathered and seen in a context to be able to make the right (or the most likely) diagnosis, which can be either of genetic or acquired origin. When the diagnosis is made the treatment plan needs to be decided in a systematic way and with a long-term perspective. In many cases patients with dental developmental defects have a long course of dental treatment ahead. Therefore it is of outmost importance that the dentist has the knowledge and the understanding that is needed to give the patient the best possible treatment. The patient's perspective is important when treatment decisions are to be made. In the most complicated cases there is often a need for a coordinating dentist with special skills (preferably a pedodontist, if available) who is able to organize cooperation between relevant specialists in other disciplines of dentistry. In this article we have focused on the most important aspects related to the diagnosis and treatment of the most frequently occurring dental developmental defects.

Keywords: Dental developmental defects, enamel, dentine, hypomineralization, hypoplasia 